\title{
The Continuing Inspirational Social Legacy of Dr Geoffrey J. Cornish MBBS, OAM (1921-2005)
}

\author{
Ricardo J. Simeoni ${ }^{1}$, Adele Perry ${ }^{2}$ \\ ${ }^{1}$ Research and Development, Neurödinger, Sunshine Coast, QLD 4575 Australia. \\ ${ }^{2}$ Invited Collaborator, Blampied, VIC 3364 Australia. \\ Corresponding author: Ricardo J. Simeoni (rsimeoni@neurodinger.com, www.neurodinger.com).
}

\section{INTRODUCTION}

This year marks several anniversary milestones of an eminent Australian and Medal of the Order of Australia (OAM) recipient, Dr Geoffrey James Cornish MBBS, abbreviated as GC throughout this letter. GC is especially renowned for a long and esteemed career in medicine, and for playing an integral, real-life role as a prisoner-of-war (POW) in World War II's tragic "Great Escape", upon which the popular 1963 movie is based. Several journalistic and literary works (cited later) that celebrate and underscore GC’s remarkable life/professional career have previously been published through or in association with: the Aircrew Association, the Australian Broadcasting Corporation, Australian ex-POW Associations, the Australians at war film archive, an authorised biography, a community radio interview of a Cornish Family member, a historiographer's (class) treatise, the Royal Australian Air Force (RAAF), various newspapers, and 60 Minutes Australia.

The esteemed medical career of GC includes, but is certainly not limited to, innovations in cardiac rehabilitation and anaesthetics, as well the establishment of vital Red Cross blood banks throughout regional Australia, all having significant community impact. Indeed, GC's life of service, that extended into his eighties, contains many other dimensions and achievements of distinction which this letter briefly summarises. Additionally, original to this letter are ten short audio messages of inspiration from GC that the first Author recorded almost 20 years ago and which to best knowledge have until now never been publically released. While other more formal audio recordings of GC are available online (e.g., award acceptance speech, interview), the audio recordings of this letter are unique in their manner of personal articulation, especially towards those within his famed walking program, and the manner in which they exude the optimism and warmth that were synonymous with GC.

Along with the aforementioned life summary and audio recordings, the letter also contains memoirs and photographs donated by the Cornish Family (via the second Author, daughter of GC), and subtly explores the spirituality of the quietly determined and modest man that was GC.

The primary GC milestone falling in 2021 is the $100^{\text {th }}$ year birthday (June) anniversary, but this year also coincides with $80^{\text {th }}$ and $75^{\text {th }}$ year anniversaries of respective capture as a POW whilst a Captain in the Royal Air Force (RAF), and returning to Australia to commence medical studies. Perhaps fittingly, the $100^{\text {th }}$ year birthday anniversary is shared with the 2021 service centenary of the RAAF which in 1939 processed GC's service application on behalf of the RAF. However, this socially significant letter in no way aims to glorify its unavoidable war aspect, but instead glorifies faith and humanity, as well as the strength of a man constituted by caring and generosity towards others, found within the confines of such conflict and other adversities.

In a perfectly succinct narrative, journalist Tara Brown of 60 Minutes Australia describes in [1] GC’s life as a touching and inspirational story of humble heroism and enduring spirit resembling an adventure novel, but being far more fascinating than any work of fiction.

As will become evident throughout the course of this summary, in the words of GC [2]:

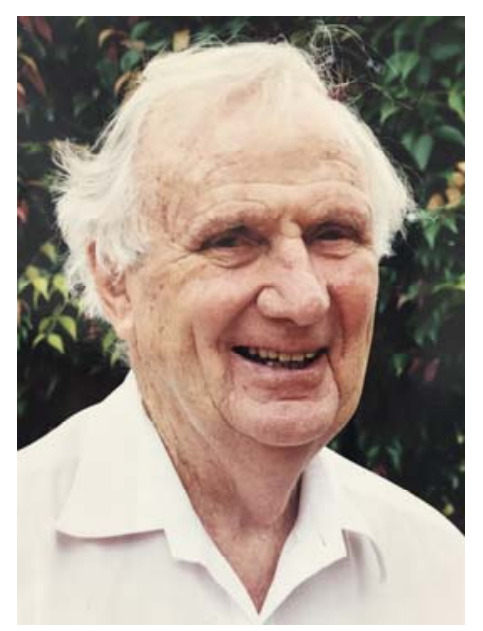

"...the two prime attributes that allowed me to achieve my dream were Faith and Persistence. I commend them to any would-be achiever."

Dr Geoffrey Cornish, MBBS, OAM 


\section{ABRIDGED LIFE SUMMARY}

Due to the "GC story" already being well memorialised, the following life summary is intentionally condensed and is summarised from [1-6], as well as from a variety of newspaper articles, Cornish Family memoirs, and personal first Author accounts (from working alongside GC). The cited authorised biography [1] is the primary written reference and naturally often provides deeper insights which all are encouraged to discover.

\subsection{EARLY YEARS AND SPIRITUAL UNDERPINNING}

GC was born $20^{\text {th }}$ June 1921 in a suburb of Perth, Australia as the eldest of a happy Family of five children (three brothers and a sister), with his parents in an ongoing act-ofkindness also, despite their own struggles, discretely financially supporting another Family during the Great Depression and additionally effectively adopting the daughter of a friend who had succumbed to long-term illness.

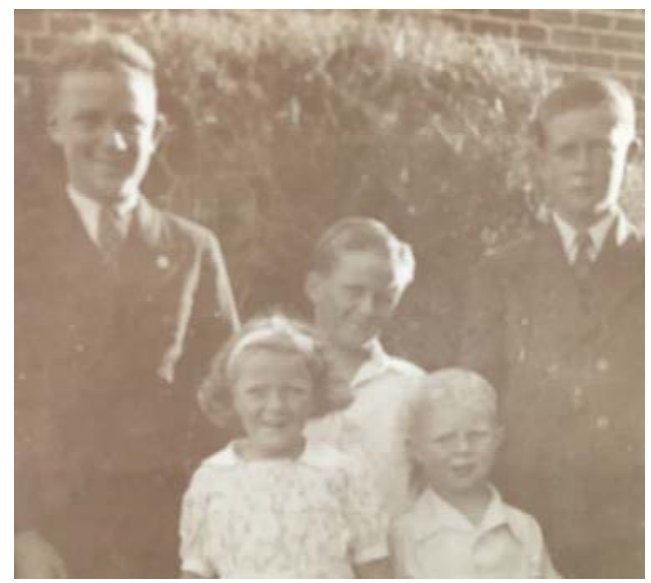

GC (left) with his siblings Gordon (centre), Keith (right), Audrey and Roy (front and youngest)

During GC's childhood the Family were not regular churchgoers, though Christianity certainly had a presence in the household (from stricter progenitor Christian upbringings such as grandparents being founding members of the West Leederville Methodist Church) and the children attended Methodist Sunday School where GC eventually taught for several years. As a teenager, GC was an active member of the Young Men's Christian Association (YMCA) gymnasium which had a strong Christian influence and GC attended Methodist Church, describing himself at the time as "quite an honest Christian" [1]. GC's then involvement in the Methodist Church is also underscored by a $4^{\text {th }}$ September 1936 article in The Western Australian with the caption "Methodist Church Scripture Examination Results"; at 15 years of age GC achieved equal second place under the "B" schools category (schools with six or more teachers) for this annual Scripture examination held by the Young Peoples' Department of the Methodist Church.

Fast forward, and the spiritual underpinnings of GC's early years emerge as being long-held within a 2004 interview [3] that asked of any final messages that he would care to leave to grandchildren, which prompted the following reply:

"I think just to reiterate that message I got at 14 (years of age) - Luke Chapter 2 Verse 52, And Jesus increased in wisdom and in stature, and in favour with God and man and if you can ever find a better way of conducting your life than that, please tell me about it. This one I know works and I trust it and it has never let me down. It is a saying that I have been able to use for the background for questioning for virtually every patient that I have treated."

The above Bible quotation, also highlighted as influential within GC's authorised biography [1], was the official motto of his YMCA club. The club's Youth Director clearly positively impacted GC who in interview [3] described the Youth Director as a great man and recalled his resonating words of:

"you won't get a better motto to model your life on than that."

Again in later years GC would reminisce in [1]:

"that little saying, that attitude, has helped me in every situation I've ever been in. It's helped me tremendously as a doctor, because I model my questioning on those four lines (to assist patients achieve a healthy life balance)",

with the four lines referring to (i) mental development (wisdom), (ii) physical development (stature), (iii) philosophical and theological development (favour with God), and (iv) social obligations to Family and Community (favour with humankind). GC also believed that following this motto helped immensely when giving medical care as a POW and, by directing the activities of POWs along its four lines (as best possible amidst obviously severe restrictions), he saved "a hell of a lot" of lives [1]. GC was additionally very respectful of all beliefs and cultures, and of course in a professional setting would never impress his theological views upon others, including patients when assessing their state through such questioning lines, and might for example incorporate line (iii) by simply referring to "serious thinking" [1]. Finally in regards to this motto, and as will become evident throughout this abridged summary, GC also lived by the extra adage from [3]:

"But do it equally, and aim for the biggest square that you can and keep pushing wider the boundaries of that square."

GC attended Perth Boys' Technical Secondary College until the end of 1935 when, at 14 years of age and due to the 
economic hardship of the post-Great Depression era, he left school to work and help support his Family (a common practice at the time). However, maintaining a dream instilled at an early age of one day becoming a medical doctor, GC continued his secondary education by attending night school. One of the first jobs undertaken during that period involved assisting an analytical chemist (and general office duties within the host company) analysing prospectors' geological samples; the work subsequently encouraged GC and his friends to travel the outback on weekends to prospect for gold, providing another source of modest income.

The above public analyst company eventually went into decline, but the work experience gained led to GC's position (commencing early 1937) of cadet in the Chemistry Department of the University of Western Australia, while still maintaining night school studies. GC joked in biography and interview $[1,3]$ that "cadet" at the time was another name for cleaner, but he enjoyed the experience and was grateful for the "wonderful attitude of helpfulness" [1] of the supervising chemistry Professor. The Chemistry Department had a photographic laboratory which GC was free to use and so photography soon became a hobby, giving an example of a self-described natural trait of being able to visualise situations that could lead to future opportunities. That is, this photography experience was fortuitous and invaluable since later as a POW GC would become the covert photographer and film developer required for forged identification document production using a smuggled camera (acquired through prison guard bribery) and hidden photographic laboratory as part of the Great Escape of 1944.

\subsection{WW II AND POW}

Following matriculation in 1938, GC commenced a Bachelor of Science degree but one month into the degree noticed an advertisement for the RAF's Empire Air Training Scheme. Subsequently, in 1939 at 18 years of age GC enlisted in the RAF (his interview record noting a "very pleasant" personality) with the adventurous hope to learn to fly and see the world, while still maintaining his dream to study medicine (since the RAF encouraged young officers to pursue further education). On $21^{\text {st }}$ August of that year GC sailed for the United Kingdom (UK) on the SS Orama with 21 other potential RAF pilots who boarded at Freemantle (like GC) or other ports of departure. During the almost two month route, World War II was declared (with the UK entering on $3^{\text {rd }}$ September), and so GC's medical plans were immediately suspended.

After flight training at RAF Ansty and Cranwell, gaining his pilot's wings, and completing a postgraduate course in navigation (that suited his precision penchant) from RAF Saint Athan in South Wales, GC undertook further operations training at RAF Upper Heyford, Oxfordshire. This combined training brought experiences on a range of aircraft, commencing with Tiger Moths, and culminated in six weeks training with Guy Gibson (Distinguished Flying Cross and
Victoria Cross recipient who as Wing Commander led the famous "Dam Buster" raids in 1943). Finally, GC was posted to Number 50 squadron RAF in November 1940. It is particularly noteworthy that a King George VI parchment (see Appendix) appointments GC as an officer of the RAF from 10 $^{\text {th }}$ April 1940, since this date holds repeated significance throughout GC's life as will become evident.

At 19 years of age GC became the youngest Captain in Bomber Command and had outlived the squadron's six weeks pilot life expectancy by a considerable margin, despite several close calls in his Handley Page Hampden aircraft which had been "battered pretty badly" [1].
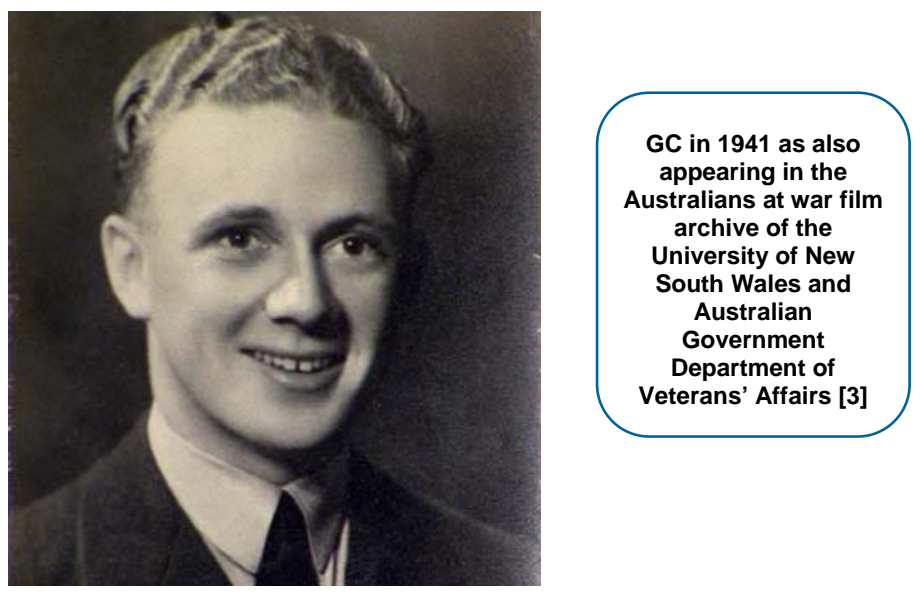

On the night of $\mathbf{1 0}^{\text {th }}$ April 1941 while flying over Eindhoven (Holland) on route to Essen (near Düsseldorf) and on his approximately $18^{\text {th }}$ sortie, GC's Hampden was brought down as a consequence of the German Army's newlydeveloped system of accurate radar-directed search lights (linked to anti-aircraft batteries) which lit him up like a "star on a Christmas tree" [1], leading to heavy damage from the cannon fire of several Messerschmitt Me110 fighters and eventual collision with the same.

Even as the Hampden disintegrated and despite the crew being lost, GC attempted to safely jettison his mortal cargo (due to Holland being a friendly country) before parachuting. The injured, oxygen-deprived and stunned GC (who later had no recollection of pulling his parachute ripcord) struggled to manoeuvre on descent in the freezing darkness, but gained enough control to land in a Nunhem farm on Easter Thursday. The farmer's Family liked and cared for GC, bathing and bandaging his wounds, with the eldest daughter, who spoke fluent English and who would come to feature again many years later in the GC story, attending to his injured foot which prevented walking. The Gestapo soon arrived on scene and GC was captured at gunpoint. Over the course of Good Friday to Easter Monday, GC was moved and interrogated between various temporary lock-up, jail and transit camp facilities (including what he believed was the same Amsterdam jail cell as Holocaust victim Anne Frank, whose Diary he was never able to complete reading due to its 
powerful emotional impact). At the end of May, GC was moved to the Luftwaffe-run Stalag Luft 1 camp (Barth) for Western Allied air force personnel where he was assigned cooking duties (that were aided by his childhood cooking duties within the Cornish household during the Great Depression).

An $11^{\text {th }}$ May 1941 article in the Sunday Times (Perth) reported on GC's change of missing-in-action status with the caption:

\section{"Perth Mother's Faith KNEW HER FLYER SON WOULD BE SAFE”,}

and the article going on to write how after three weeks of being missing in action GC was now reported as a POW.

In April 1942, 12 months after being "shot" down, GC was transferred approximately $350 \mathrm{~km}$ to the East Compound of Stalag Luft 3 camp (Sagan) on the Germany/Poland border (in preparation for transfer to the under-construction "escapeproof" North Compound for troublesome POWs, with the transfer eventuating 12 months later). GC attributes both of his transfer dates to $\mathbf{1 0}^{\text {th }}$ April [2] (the transfer to the North Compound for the POW collective occurred over several days from March to early April).
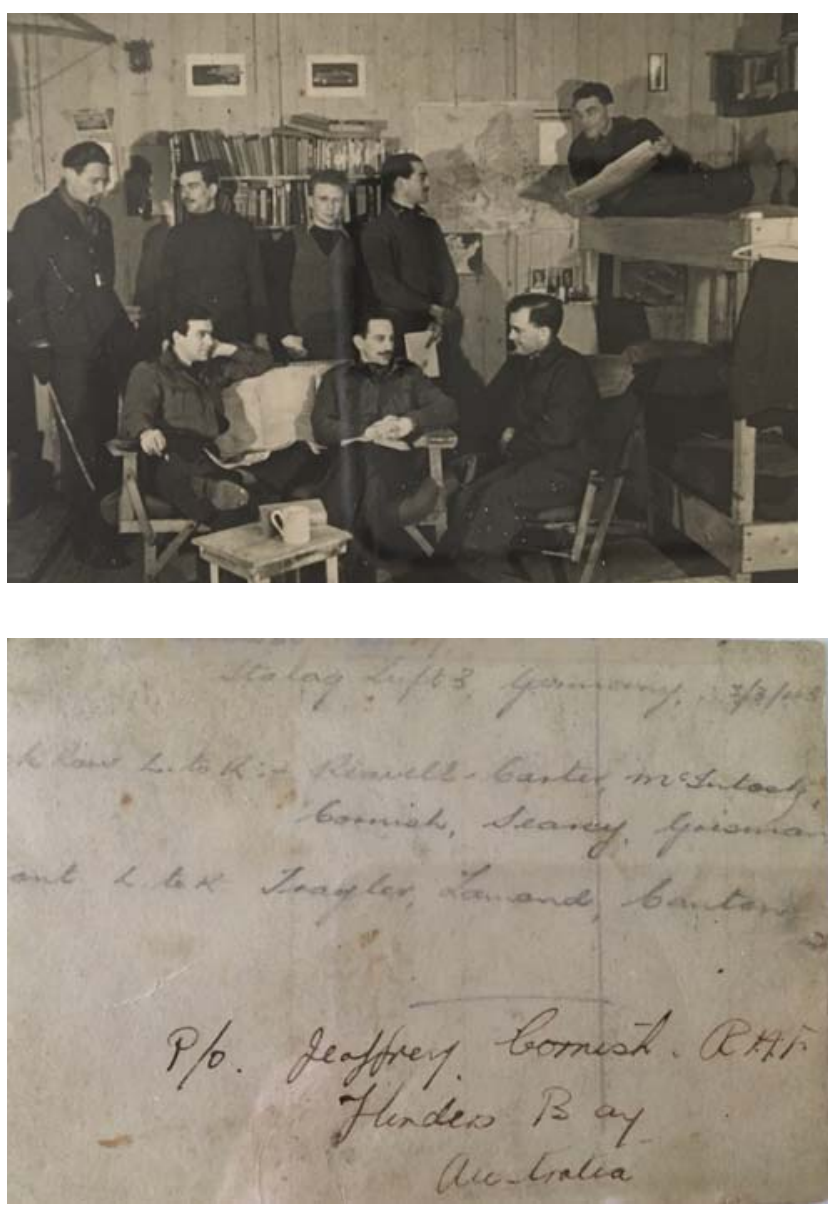

The depicted Stalag Luft 3 lumber yard with GC serves as a reminder of an escape attempt that is detailed within [1]. In brief, the opening of the North Compound was rushed due to swelling POW numbers, and so its site had not been fully cleared. As part of an escape plan, GC and a Czechoslovakian friend attempted to swap places with Russian labourers who had been brought into the camp to clear the site (by felling pine trees used for construction) which required the Russian labourers' back-and-forth movement in groups through the camp gates (i.e., work beyond the camp perimeter). As told in [1] in regards to GC, his Czechoslovakian friend, and their escape plan:

"They grew beards for a few days, smeared themselves with filth, donned Russian uniforms and hid."

GC was unfortunately recognised by a German guard after a spurious head count, leading to 14 days in the "cooler" on bread and water rations, but with new-found Russian mateship since the labourers saluted his escape attempt.

Stalag Luft 3 Camp including: GC's hut with occupants identified in GC's hand writing $3^{\text {rd }}$ March 1943, and GC working carrying lumber
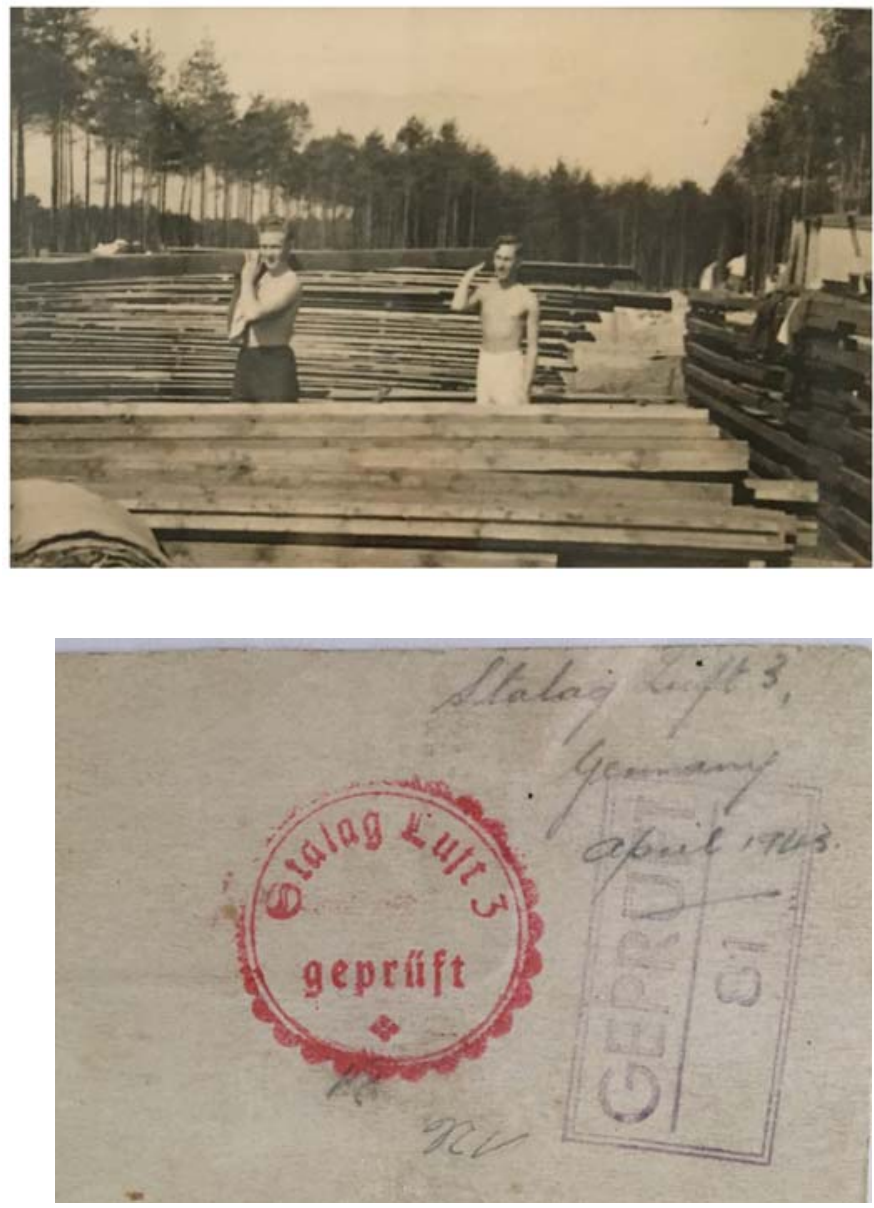
GC reignited and shared his medical aspirations with medical officers of both Compounds, in due course acquiring medical texts for study and taking regular mentoring and tuition from a British POW doctor with whom he developed a "lovely rapport" [1]. In becoming camp medic, GC assisted this doctor every morning and afternoon during North Compound hospital ward rounds and acted as his interpreter during consultations with the camp's German doctor. Motivated by a desire to learn and also by the realisation of its life-and-death escape implications, GC had also studied German during this period of incarceration and became perfectly fluent as a result of a meticulous morning study routine which ultimately facilitated the medical interpreter role. GC would also come to informally learn some Polish and Russian, with language affinity aided by, and demonstrated during, his time at RAF Saint Athan which was quite cosmopolitan due to its international flyer contingent.

At 22 years of age GC became an integral contributor to the famous Great Escape from the North Compound, with the following escape attributions:

- A key planner (some of the planning meetings took place in his quarters).

- As a consequence of his German fluency, was a member of the German Bribery Department (a subgroup of the well organised Great Escape Committee) and one of only seven POWs allowed to speak with guards.

- A tunnelling operations shift coordinator and one of the tunnellers (not being claustrophobic).

- Photographer and film developer for forged identification documents.

- Selected within the first group of 15 (position 8) of approximately 200 potential escapee POWs (76 actually managed the overnight escape).

Causing much anguish to GC was the eleventh hour decision to sacrifice his escape position because of the greater need to remain behind and apply his medical skills in the caring of the sick by continuing to learn from his mentoring doctor. GC soon followed his mentor to the understaffed hospital of the new Stalag Luft 3 Belaria Compound a few kilometres away (and which in short time housed 500 ill and injured men). The decision also allowed the continuation of GC's provision of intelligence information that he was able to covertly hear as a consequence of his hospital standing. Having previously been placed in the cooler for an escape attempt, the decision to remain also went against GC's natural escape instinct which added to his anguish (GC's Family also recount how body scars were inflicted by guard dogs during a previous escape attempt [6]). Tragically, 73 escapee POWs of the Great Escape of $24^{\text {th }}$ March 1944 were recaptured (50 being callously executed by the Gestapo on the orders of Hitler), with only three making it home, again adding to GC's anguish. Also executed by the Gestapo was Squadron Leader Roger Joyce Bushell, the mastermind (code-named "Big X") behind the intricate and sophisticated planning of the Great Escape. Roger Bushell was a highly intelligent man (a qualified Barrister), European skiing champion, and according to GC a very bright and well-humoured conversationalist who frequently pushed German authority within the camp to its limits.

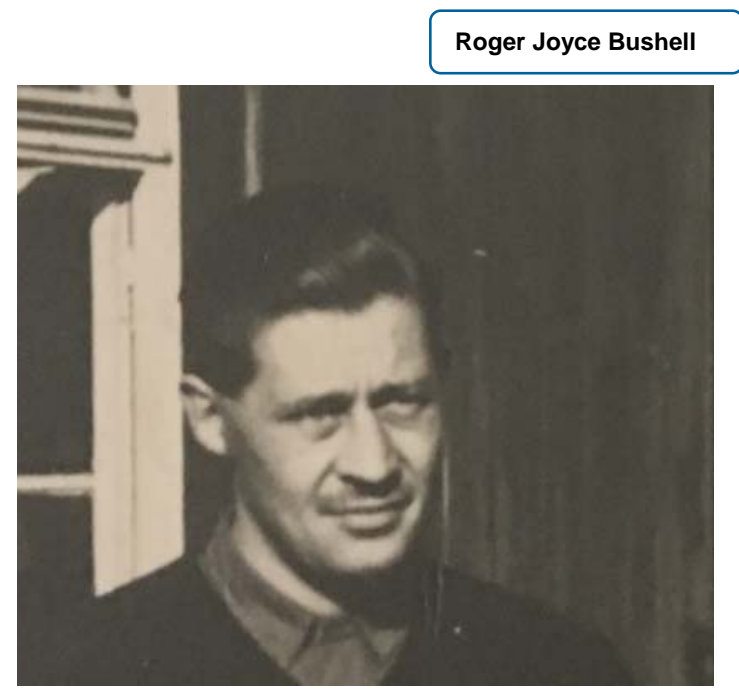

Due to advancing Russian forces, in January 1945 and under the order of Hitler, all Stalag Luft 3 Compounds, except (temporarily) the new Belaria Compound where GC was left in medical charge, were evacuated with immediate urgency by a forced westward march across Poland, Czechoslovakia and Germany. This march, an historical event of harrowing conditions to which this brief summary cannot give due justice, involved approximately 10,000 POWs and commenced in extreme weather (e.g., gales, deep snow and sub-zero temperatures) and involved other circumstances of depravity (such as distances covered) which contravened the Geneva Convention for POW treatment. The day and night march of the $5 \mathrm{~km}$ long column concluded in Nuremburg some $500 \mathrm{~km}$ away (part of the journey was completed via loading into "cattle-trucks") where POWs were again incarcerated in Stalag Compounds.

The Belaria Compound with GC was also eventually evacuated to Nuremburg via train (another cattle-truck-type situation with feeble men stacked three-deep upon stretches in some cases). After approximately two months in Nuremburg, the forced march, including GC as a marcher, continued another ten days onto Moosburg (approximately $60 \mathrm{~km}$ from Munich). Together with a colleague, GC carried medical supplies and tirelessly worked day and night along the column to provide urgent medical care and patch-up the many in pitiable states as best possible (this care was critical since those who could not keep up risked being shot by the SS). The sanitation at the makeshift camp at Moosburg was 
appalling with over 300 men per tent (and still some sleeping outside due to too few tents), but it was here on $3^{\text {rd }}$ May 1945 that GC was finally liberated by United States troops under General Patton, after a total of over four years as a POW.

During liberation American troops made an urgent announcement calling for any POWs with medical training. GC came forward (the only one to do so - forewarned, some were "speechless with what they had seen" [1]) and was subsequently taken to Dachau concentration camp for triage duty which GC described as the worst two days of his life and furthermore [1]:

"the worst scene I can ever remember, I never want to see anything like it again."

In celebration of the human spirit GC went on to say [1]:

"To see that look of incredible disbelief, relief in somebody who was so ill that they virtually had nothing left, but they clung to life so fiercely you could see that they knew now that ... it was all worthwhile, there was hope."

During those two days GC discovered and rescued a young girl whose life would have been further gravely endangered if she were lost amongst transferees, and he was able to hide her in a laundry trolley and then bundle into an ambulance to safe care (later the young girl as an adult amazingly recounts the story of being rescued on the popular Antiques Roadshow UK television program, as emotionally retoled by the second Author in $[6]^{1}$ ).

Following liberation GC, exhausted and weighing less than $40 \mathrm{~kg}$, returned to the UK for recovery which in short time was unfortunately hindered by incongruous circumstances. Viz., on a wet road, a speeding and cornering Belgian Army lorry crashed into GC (driving a borrowed Austin car), who subsequently awoke three days later with an injured knee and broken right hand in Stratford-upon-Avon Hospital. After recovery, GC studied Science (at first year university level) and taught German at the Laurence Shearer School in Rugby, where he also played rugby (aided by his RAF operations time in Oxfordshire, where he had received rugby training from his Flight Commander, an England representative player).

\subsection{MARRIAGE, MEDICAL STUDIES AND FAMILY}

On $20^{\text {th }}$ May 1946 GC returned to Australia (and onto the welcoming sight of Perth's blooming Kings Park wildflowers which had been beloved since childhood) to finally commence his medical studies (almost seven years after joining the RAF) at the University of Western Australia. Here, GC became the science students' representative on the student union where he met Shirley Strickland AO, MBE (gold medallist at three consecutive Olympic games), also a

\footnotetext{
${ }^{1}$ The rescuing of the young girl who recounts the event as an adult is given most likely attribution to GC in [6], but the event had in fact been verbally verified by GC.
}

student representative, who would go on to graduate with a Bachelor of Science (Honours) in Physics and become a lifelong friend.

GC married and his wife (Myra), who was a steadying influence upon the challenges of an unfamiliar unstructured post-war environment, was critical to GC's medical study completion and later career successes (and see Subsection 3.4 and [1] for insights into her many other admirable qualities). After his first year of medical study, GC transferred to the University of Melbourne and during this time was mentored, via lectures and surgical tuition, by the inspirational Sir Edward "Weary" Dunlop, renowned for treating the sick amidst extreme hardship and deprivation on the infamous (for its brutality) Thai-Burma Railway (on which approximately 10,000 Australian POWs worked as part of the Changi prison network in Singapore). The kindred pair would become friends and exchange POW stories, and the fact that GC had been a POW for a longer period of incarceration was greatly respected by Weary Dunlop. GC would later become the anaesthetist for some of Weary Dunlop's surgeries.

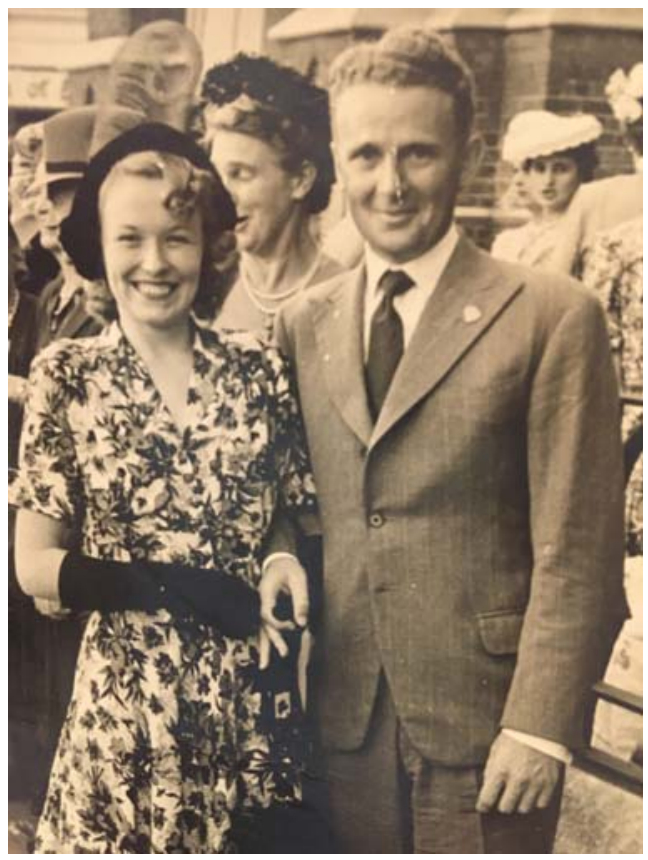

GC and wife, Myra, the day after they married, $16^{\text {th }}$ May 1946 Perth

During his medical training, GC found a variety of ways to make financial ends meet including as a wedding and $21^{\text {st }}$ birthday cake decorator. GC had even developed his own enhanced icing formula and went on to decorate his daughters' wedding cakes, giving further examples of his ever-innovating mind and the quiet, gentle side to his nature that were present from a young age. The cake designing skills were in fact learnt as a child from his Aunt and even earned GC a modest income as a teenager through 
approximately five wedding cake orders from neighbours and friends, with a $6^{\text {th }}$ October 1937 article, on a $21^{\text {st }}$ birthday celebration, in the Daily News (Perth) stating in regards to $\mathrm{GC}$ at 16 years of age:

"The birthday cake, beautifully decorated and iced by Master Geoff Cornish, held pride of place.”
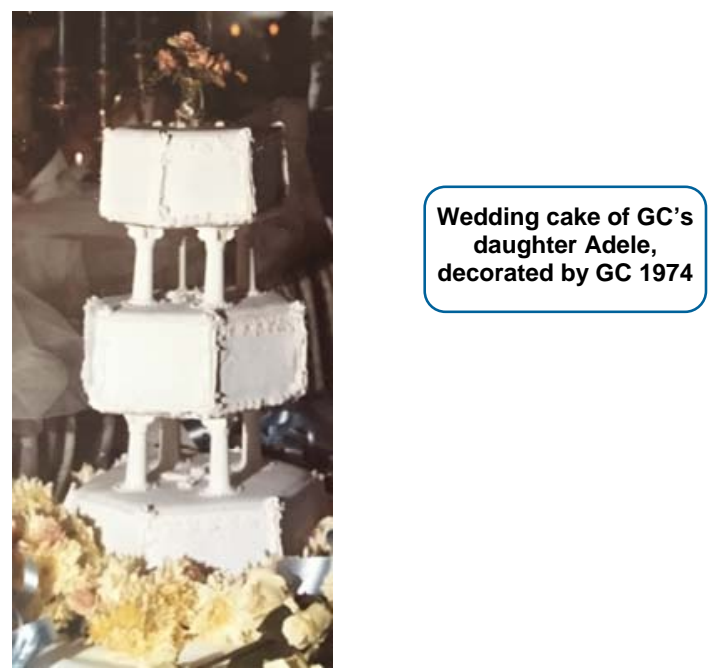

Other employment to make ends meet during this period of medical training was undertaken by GC at Melbourne's Henry Bucks menswear store which today is still in operation, but additional employment opportunities were also undertaken including labouring.

The period of medical training in Melbourne also saw the birth of the Cornish's two daughters (Adele and Sue), with second daughter Sue arriving 24 $4^{\text {th }}$ April 1951 and GC's Bachelors of Medicine and Surgery being conferred by the University of Melbourne a few months later on $23^{\text {rd }}$ October.

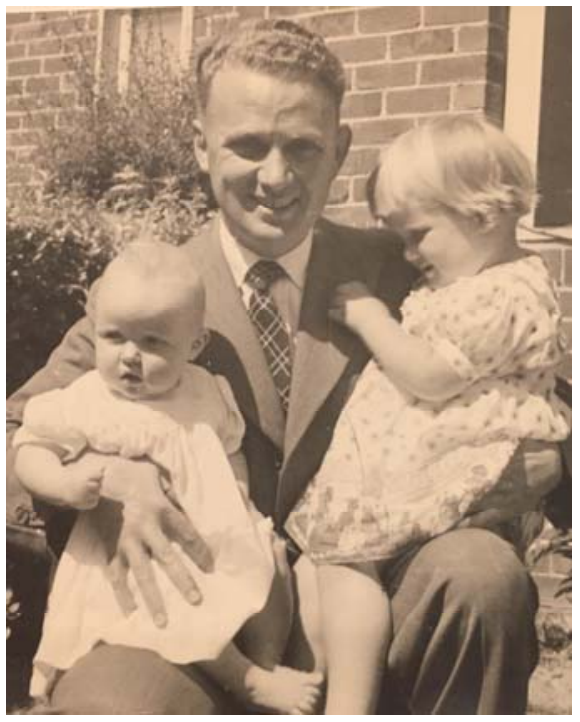

GC with daughters Adele and Sue (youngest) 1951

\subsection{EARLY DOCTOR YEARS}

With his first earnings as a practicing doctor, GC purchased a bracelet for Myra. Today the bracelet with added meaningful charms, including that of a silk producing caterpillar, is treasured by the Cornish Family. The gold caterpillar charm is symbolic of, and was received as part of, GC's membership to the "caterpillar club", founded in 1922 by Leslie Irvin (Canada) for those whose lives had been saved by (originally silk-threaded) parachutes in nonrecreational/training circumstances.

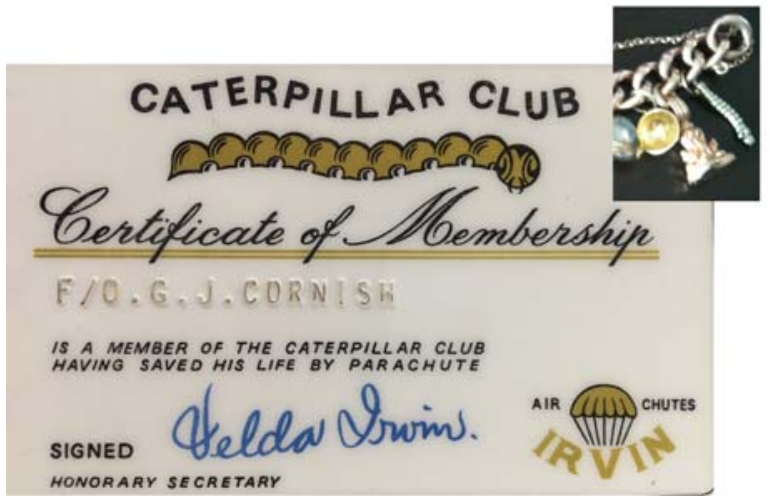

GC's "Caterpillar Club" membership card with silk caterpillar charm

Though GC's wish was to specialise in paediatrics, financially he was obliged to enter general practice, leading to a 1952 posting in isolated Bronte Park, Tasmania (a town created for approximately 2000 people by the Tasmanian Hydroelectric Commission). The hydroelectric scheme was largely staffed by displaced German, Italian and other European immigrants, and GC was publically vocal in his strong stance against the ignorance of racism directed towards these immigrants (see Subsection 3.6 for further details). The immigrants' work was dangerous with a high fatality rate, leading to GC instigating a local blood collection centre that he and others would regularly staff this was the first Red Cross blood collection centre established outside of a capital city in Australia. The collection centre saved many lives and provided needed additional blood stocks for Hobart. However, the establishment of this and other regional blood transfusion services to follow (see below) was never easy, having to overcome opposition and obstacles from central authorities on multiple occasions. As was required in these instances, another side to GC's nature was as a strong and unwavering man [6]:

"when he dug his heels in, look out!, he was very determined."

The period in Bronte Park was described as a happy time and the opportunity to immunise many local children 
provided much satisfaction for GC. However, due to the isolation, GC left Bronte Park in 1953 for general practice in Drouin and additional work at the West Gippsland Hospital in Warragul (Victoria). Blood supply was a familiar problem and so in 1954 GC was again instrumental in establishing a remote blood collection base; by 1988 the base at the West Gippsland Hospital had become the model for 58 rural blood banks throughout Australia.

In 1955 GC and Family moved closer to Melbourne by joining a practice in the larger centre of Frankston (whilst also enjoying Family life living on a farm), and it was here that at times GC assisted Weary Dunlop's surgeries as an anaesthetist. In a now familiar scenario, GC was instrumental in establishing a mobile blood bank but furthermore became the Regional Director of Blood Transfusion Services. These primary roles in establishing the first permanent rural Red Cross blood bank in regional Australia, and the services which followed, are more personally addressed with quotation from GC within Subsection 3.5.

In 1960 (still in Frankston) GC moved full time into anaesthetics and developed several innovations in the area of portable anaesthetic devices. For example, building upon a mobile resuscitation system which he developed in Drouin, GC constructed a fully equipped mobile anaesthetics department in a van. Practicing from Frankston to Warragul the associated business flourished, with its eventual successful expansion involving some 18 anaesthetists and disproving the sentiments of many naysayers.

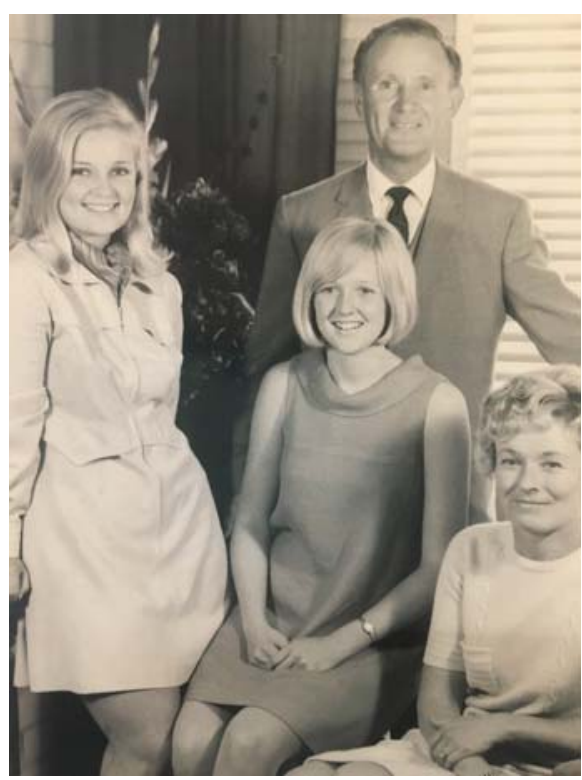

Cornish Family portrait 1970

\subsection{LATER DOCTOR YEARS AND COMMUNITY SERVICE RECOGNITION}

Sadly, Myra had been frail for some years due to a significant heart condition (manifesting since even before marriage and see Subsection 3.4 for further details). In 1957 Myra had suffered technical heart failure as a consequence of two failing heart valves and required surgery, the first of several over the years to follow, including artificial valve replacements in the pioneering days of this procedure.

GC's determination to care for and rehabilitate Myra, with whom he spent much time within coronary care units during recoveries, was the motivating factor for dedicating his later medical years to helping heart attack survivors and more generally those with heart conditions. Based around Myra's recovery, GC developed an innovative cardiac rehabilitation approach for the National Heart Foundation.

Prompted by the climate benefits for Myra and winning a trip (via raffle) to the Gold Coast, in 1981 GC moved to the Gold Coast and adapted his cardiac rehabilitation approach such that it became the basis of his future career. The lifeimpacting-for-many and internationally recognised approach included an extremely effective (both medically and socially) and renowned walking program. Several other examples of GC's medical innovativeness and inventiveness may also be cited (e.g., companies formed around custom home and holter-style electrocardiogram monitoring devices), and see Subsection 3.7 and [1] for other invention examples, including nonmedical and what some might consider as being humorously practical.

The increasing success and widespread recognition of GC's cardiac rehabilitation approach is well highlighted by a $30^{\text {th }}$ January 1992 article in the Western Tiers (Tasmania). With the caption of "WALKING FOR FITNESS", the article states in relation to the approach:

“... has doctors from all over Australia and overseas coming to the Gold Coast to observe .... They (participating patients) were very extravagant in their praise of the doctor who had done so much for each personally.",

with one participant quoted as :

"The Heart Foundation books are very good on the topic; but Dr Geoffrey Cornish on the Gold Coast has it down to a fine, exact art."

GC was quietly proud of the subsequent Cornish-named walkway adjacent to the Kurrawa Surf Lifesaving Club from where his authorised biography was launched (as a related aside, GC as a teenager was an active member of the City of Perth Surf Lifesaving Club and was typically assigned to resuscitation within surf teams and competition - clearly a forerunner to an extraordinary medical career). GC also had a weekly segment on Gold Coast radio, advocating how to look after one's health, and as always was extremely generous towards the community that he served (e.g., 
funding/supporting research projects within, and employing graduate cardiac technicians and exercise physiologists from, Griffith University Gold Coast).

GC also served the community through his positions within various associations and committees (e.g., involving air crews, aging, POWs, the Retuned Services League, and Rotary for which he held membership since 1953). In 1993 GC was awarded the Medal of the Order of Australia for:

"services to medicine particularly through the development of cardiac rehabilitation programs and to the community",

and was additionally awarded the following accolades between 1993 and 2001: Gold Coast Citizen of the Year; first Paul Harris Fellowship (awarded by Rotary); and Honorary Doctor of Griffith University. However, of all his medical achievements GC's exuberance and quiet pride was perhaps most saved for "his babies" [6] that he delivered into the world at early postings such as West Gippsland Hospital.

\subsection{CIRCLE OF LIFE}

GC attended $25^{\text {th }}(1969), 50^{\text {th }}(1994)$ and $60^{\text {th }}(2004)$ European-based anniversaries of the Great Escape. The $60^{\text {th }}$ anniversary was particularly emotional, returning to the ruins of Stalag Luft 3 North Compound in Sagan and attending a British military cemetery for murdered escapers in Posnan for the first time (an event covered by 60 Minutes Australia); the tragedy of the POW who took GC's place in the Great Escape in particular tearfully impacted GC. However, these emotional reunions were very cathartic and the meetings with those involved in the Great Escape tapestry represents humanity at its best. As examples, in 2004 GC presented flowers to the famer's daughter who attended his wounds before capture by the Gestapo (she recounted that after the war she and 300 other children were sent to Scotland to recover from starvation), and in 1994 when landing in Berlin GC was met by and socially caught up with Stalag Luft 3's most senior guard (who was respected for being fair, professional, unbribable and responsible for the distribution of Red Cross parcels that reportedly always remained intact).

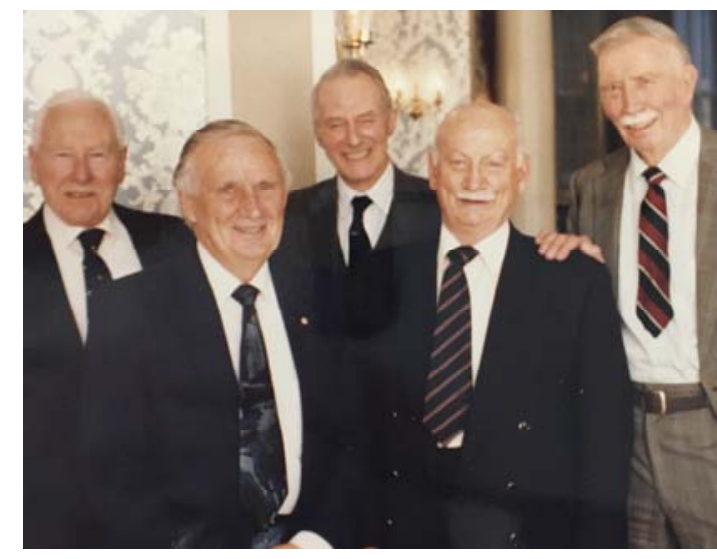

RAF reunion in the UK 2002/2003 (the gentleman on the far right is wearing an RAF tie which GC also often wore)
Such experiences no doubt helped form GC's documented strong views on issues such as the 2001 Tampa and Children Overboard crises in Australia. GC believed in extending generosity of spirit by educating and upskilling such asylum seekers and refugees, with for example a flow-on benefit being an ability to make positive changes when one day returning as leaders within their homelands, just as he and other POWs somewhat analogously benefited from educating themselves amidst the restrictions of POW life.

GC was never financially motivated but rather his intrinsic motivation for the practice of medicine came from bringing happiness to others through their good health [6]:

"I'm not in this world to make money, I'm here to make it a little healthier by the time I leave it."

Demonstrating its governance within GC's spirituality, this non-financial motivational sentiment was more recently reiterated by the second Author who had recited the given quotation within [6].

At his Honorary Doctor of Griffith University acceptance speech, GC stated:

"Now, having been in medical practice for 50 years I still have that tingling in the pit of my stomach. As Fred Hollows said: Try and leave the world a better place."

GC passed away in 2005 as a result of melanoma which he attributed to the many hours spent surfing and surf lifesaving during his early years when sun safety was an unknown. Amidst all of the deserved superlatives used for GC, perhaps one that is less used, but only because it is taken as a given within GC's many achievements, adventures and adversities, is courageous, and that certainly applies to GC's tackling of his final challenge. Prior to his passing when interviewed on being remembered GC again returned to Luke 2:52 and his Christian beliefs within [1] and [3] respectively:

"I think it goes back to my little motto you know about expanding your life always along the four different avenues and if you can present what you've done, how you've done it so that people say - that is the way to go - then ... then alright, I've incorporated Christianity into it as well."

\section{“That was a wonderful motto and it never let me down.”}

Though he knew of its planning, sadly GC did not quite get to see completed a schoolhouse built at the Phang $\mathrm{Na}$ Naval Base near Phuket (with a brass plaque hanging over its door in GC's memory). The schoolhouse's area had been decimated by the catastrophic 2004 Boxing Day Tsunami. The second Author was the coordinator between her Bangkok and GC's Surfers Sunrise Rotary Clubs for the project and, in a primary carer role, also commuted about every six weeks from Bangkok (home of ten years with husband) to the Gold Coast for approximately the last ten 
months of GC's life. Many “amazing people” (members of GC's and other Rotary clubs) in fact travelled to Phuket to help construct the schoolhouse under Rotary's Global Grants Scheme, which funds large international sustainable and measurable activities including humanitarian projects. The above demonstrates the philanthropic influence that GC had, and continues to have, on the lives of others and the enormous admiration many hold for GC.
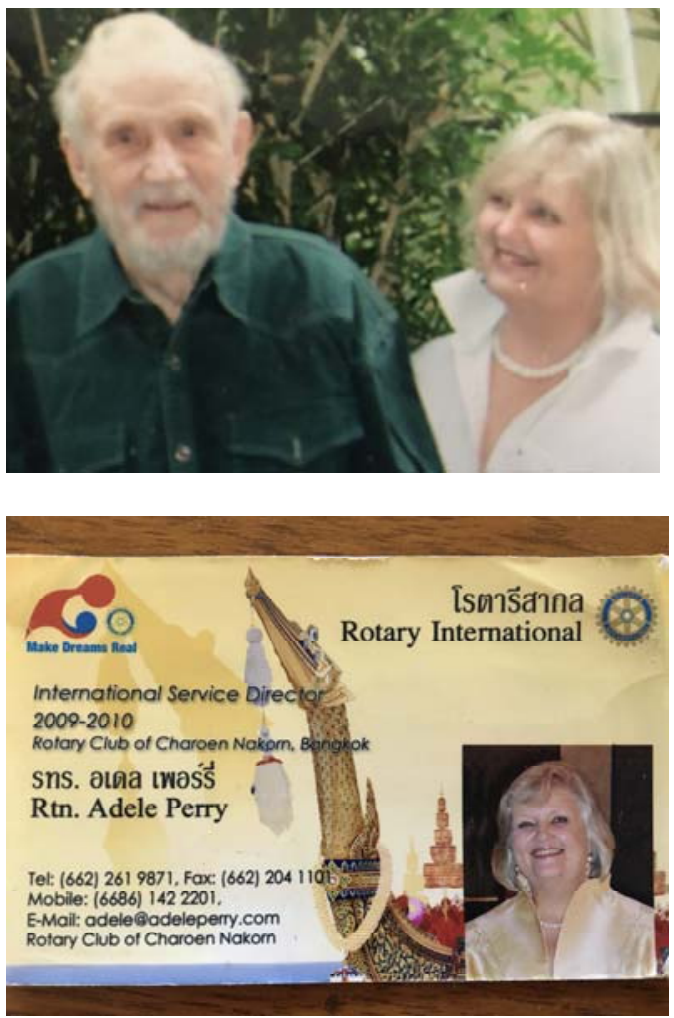

GC with Daughter Adele as primary carer, and Adele's Rotary Director identification, a reminder of the School house built in tsunami-ravaged Phuket just after GC's passing and bearing a brass plaque in his memory

Finally, given GC's remarkable life it is not surprising to find remarkableness in his passing on $\mathbf{1 0}^{\text {th }}$ April 2005 which prompts contemplation of the existence of some higher or universal plan in regards to the date and GC's life since, as highlighted throughout the presented abridged life summary, $10^{\text {th }}$ April was also the date on which GC was brought down over and captured in Holland, as well as the date from which GC was appointed by parchment as an officer of the RAF. Additionally and as also noted within the abridged summary, GC identified $10^{\text {th }}$ April as the date on which he was transferred to the East Compound of Stalag Luft 3 camp, and then again to the North compound 12 months later [2]. It is also noteworthy that in 1941 (when brought down and captured) the date fell on Easter Thursday, and so each year up until his passing GC would commemorate the event by hosting an Easter Thursday social get together with friends. Hence, it is fitting to conclude this abridged life summary, that in part celebrates GC's $100^{\text {th }}$ year birthday anniversary, with recognition of the importance that the $10^{\text {th }}$ April date (the $100^{\text {th }}$ day of the year) played in his life.

\section{SECOND AUTHOR REFLECTION}

This Section is written from a personal perspective due to the second Author's relationship (daughter of) GC, with the slightly informal writing style of memoirs retained for authenticity:

What an honor, privilege and blessing to have had Geoffrey James Cornish as our Father!

\subsection{OUR CHILDHOOD}

My sister Sue's and my upbringing was amazing, happy and well-balanced. Our formative seven years plus were idyllic, spent on a 45 acre farm near Frankston, Victoria. My father adored the open space and I can still hear him singing one of his favourites, "Don't Fence Me In" (understandably, after having been a World War II POW in Germany for four and a half years, aged 19 to 23).

\subsection{TEACHING BY EXAMPLE}

Whether while taking us for trailer rides around the paddocks, helping with chores, constructing our dream cubby house in a tree, milking the four cows, stoking the briquette hot water service, feeding the animals, fixing the windmill or doing minor household chores, he made it fun and laid a great foundation/standard for our entire lives.

\subsection{SOCIAL INTERACTION}

As a general practitioner, he frequently made house calls to his patients in need. At weekends, he'd often say:

"Come on girls, I'll only be 20 or 30 minutes. You can say hello to my patient's family and perhaps have a drink."

This even applied to Dame Elisabeth Murdoch at her home, Cruden Farm, which was less than two miles from ours. Inevitably, Dame Elisabeth would kindly ask her housekeeper to invite us into the kitchen for homemade biscuits and lemonade. To this day, the kitchen remains the same, even after 62 to 65 years!

Other times, he would be operating at the Children's Orthopedic Hospital (the Mount Eliza branch of the Royal Melbourne Hospital). During school holidays, he'd take us with him, where we'd spend time playing with many of the children who were often bedridden or were learning to use calipers, braces, etc. Many were victims of Polio. Needless to say, the drive home was always quiet. Tired but humbled, because we realised how fortunate we were to be healthy. Dad never had to say a word. Lesson well learnt! 


\subsection{BE CONSIDERATE, CARING AND THOUGHTFUL}

Our darling Mother, Myra, suffered from a damaged heart caused by rheumatic fever as a 15 year old, so a great deal of our upbringing was focused on helping to care for her and to make her as comfortable as possible. A calm, relaxed home was paramount. In 1972/73, two artificial heart valves gave her another eleven years of life. A loving, fun, stoic, brave and determined lady who never complained. We all adored her.

\subsection{ROTARIAN FOR OVER 50 YEARS}

Joining at around 30 years of age, while we lived in Drouin, Victoria. One accomplishment of which Dad was particularly and quietly proud right up until his passing, was to approach Red Cross Head Office to establish the first regional, permanent blood bank in Australia, at the local Warragul Hospital (as detailed within Subsection 2.4). In Dad's words:

"Far too many people were dying unnecessarily, due to no access to Blood Transfusions."

Through the Rotary Student Exchange program, we hosted many overseas students to stay (for three months), including a wonderful girl from Malaysia, with whom I remained close friends, till she sadly passed away two years ago.

We were also encouraged to help with raising funds for charity, whether it be door knocking for Red Cross, waitressing at the local art gallery for Frankston Hospital or Menzies Boys' Home (a local orphanage), with Dad advocating:

"It's good to give back to the local community and to help some of those less fortunate."

\subsection{LOYALTY AND FRIENDSHIP}

My Father's first job as a qualified doctor was in Bronte Park, Tasmania. Many of the workers had arrived, after being brought from Europe as Government-assisted men to work in Bronte Park on the new hydroelectric scheme. Several of these brave men became lifelong family friends.

Being so soon after the end of Word War II, there was an undercurrent of intolerance, and sometimes hatred, of the many ex-German army Hydroelectric Commission workers. These feelings finally erupted at a community meeting. After the verbal escalation, my father quietly stood up, explained his time as a POW in Germany and said:

"They were doing their job, during the war, I was doing mine. I feel no animosity to any of these men and neither should you."

Nicki (Nick, or Klaus in German) Gottschalk and Orrie Fruehauf were two of the men. Nicki had begun the scheme on pick and shovel but had progressed to the jackhammer when GC went to the hydroelectric scheme's administration to find someone suitable for blood typing training. A records search indentified Nicki as a candidate due to his having undertaken first year medical training before the outbreak of the war, and once he'd finished his contract at Bronte Park my father helped him to complete a Pathology degree and then to secure a job at Warragul Hospital (Pathology Department). In the latter years, Nicki was Head Pathologist at Bairnesdale Hospital, a Rotarian, and a highly respected man.

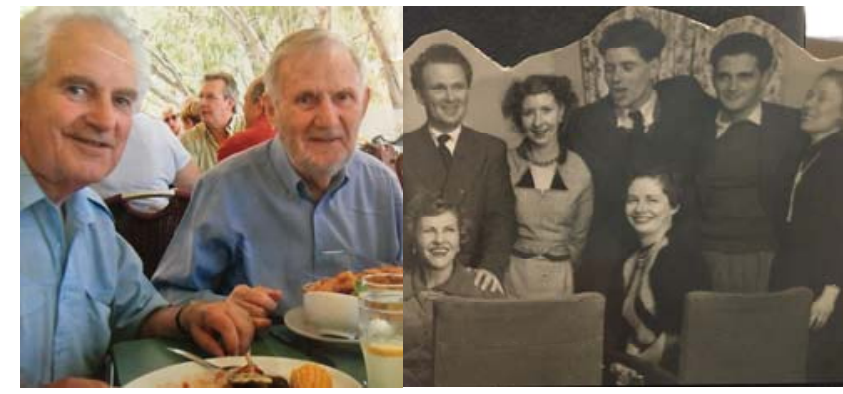

GC with good friend Nick Gottschalk at the 2004 launch of GC's authorised biography on the Gold Coast (left), and a celebration night in Bronte Park, Tasmania in the early 1950s (right), with Nick next to Myra on the far right and GC standing behind Peg Rayward who with husband Ralph (a hydroelectric Engineer) were also close lifelong friends

After completing his work contract, Orrie moved across to work on the Snowy Mountain hydroelectric scheme. He became one of three who founded Falls Creek Ski Village, building two of the first ski lodges: Winterhaven and later Snowhaven. Both our dear friends Nicki and Orrie married, had families of their own, and were in close contact until their passing, both not that long ago.

It's also worth noting (as per Subsections 2.3 and 2.4) that as a medical student, my father was fortunate to have been mentored by ex-POW Sir Edward "Weary" Dunlop. An admirable man who also became a lifelong friend.

\subsection{LATERAL THINKER, AHEAD OF HIS TIME}

Geoffrey James always loved to think outside the box. I'm sure on many occasion he'd be thinking to himself, "Why not?". Some examples that come to mind include:

- Building a hydrofoil boat in the mid 1960's for an interest.

- Establishing an organic rose farm.

- Designing new, portable unaesthetic machines (for his work).

- Establishing the Cornish Walking Program both in Victoria and Queensland.

Note that for the above-mentioned walking program he also discussed his idea to have "a special watch" to monitor your heartbeats, etc. while exercising (very similar to the later designs of "Fitbit" and so he was again ahead of his time). 
Unfortunately, he couldn't proceed with the development of this idea, due to lack of funds. But the amazing lateral thinking was there.

\subsection{SUMMARY}

In summary, he lived every day of his life to the fullest: what a great example to us and others! Oh so many adjectives apply, but these in particular:

o Focused, never lose sight of your dream

$\begin{array}{llll}\text { o } & \text { Loving } & \text { o } & \text { Kind } \\ \text { o } & \text { Intelligent } & \text { o } & \text { Loyal } \\ \text { o } & \text { Compassionate } & \text { o } & \text { Understanding } \\ \text { o } & \text { Lateral thinker } & \text { o } & \text { Supportive } \\ \text { o } & \text { Thoughtful } & \text { o } & \text { Approachable }\end{array}$

and so much more. A gentle, quiet achiever who loved apple pie and simply wanted to "leave this world a little healthier". There's no doubt he did this in bucket loads.

RIP Geoffrey James. Will always love and miss you.

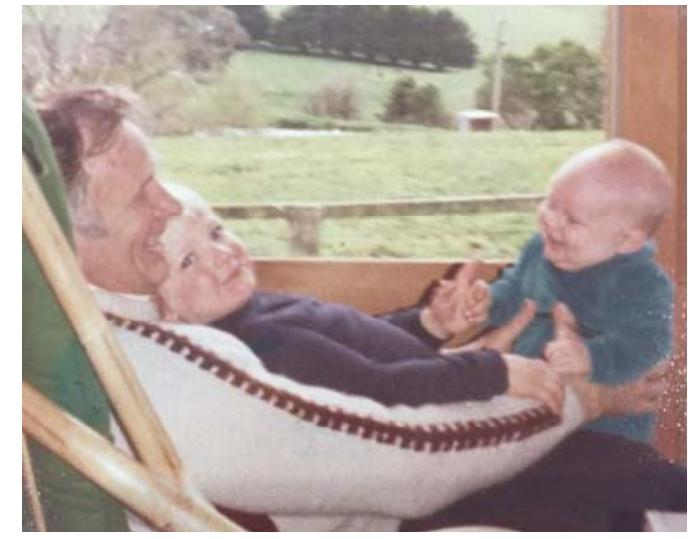

GC enjoying time with grandchildren on Family farm 1980

\section{INSPIRATIONAL GC AUDIO MESSAGES AND FIRST AUTHOR REFLECTION}

The following "final years" first Author reflection, which culminates in links to newly-released inspirational GC audio messages, is based upon a time (2002 to 2004) of professional collaboration in relation to GC's cardiac rehabilitation practice (especially his walking program and including the oversee of an engineering honours student within that program).

GC was a generous, humble, humorous and warm gentleman with a quiet dignity respected by all. In particular, GC's generosity via personal/professional inclusiveness towards the first Author, as a relatively early career academic, was extraordinary and all in the medical and academic professions should be inspired by the mentoring and respect that he offered towards all others. The energy and intellect of the man, in his eighties at the time, were truly remarkable.
The Author vividly recalls GC's exuberance in embracing new project ideas and initiatives under the umbrella of his cardiac rehabilitation practice, and willingness to share and even volunteer many accounts of his life experiences. These accounts included GC's POW experiences such as radio concealment, and the bribery of, and humorous sleight-ofhand deceptions played on, Stalag Luft guards by those involved with the Great Escape, in-line with some of the factual aspects of the namesake movie. It was subsequently learnt that, like for many who experience the horrors of war, for most of his life GC was understandably closed about POW experiences, and so the first Author was indeed privileged to hear these narratives first-hand.

Without a doubt, the brief personal account here will simply reiterate the accounts of all others whose lives GC touched. At the time of collaboration, the first Author was not aware of GC's four guiding lines of medical practice, and life in general, that are based upon Luke 2:52. However, such was GC's care for all, on reflection it is now clear to the first Author how during interactions GC would subtly enquire as to the personal and professional wellbeing of others and generously offer friendly amelioration to enhance their progress along the four guiding lines.

The following GC audio messages, which the first Author recorded in May 2002, were made for a cause that GC passionately supported (and in the fullness of time these messages now constitute a fitting memorial). In 2005 after GC's passing, the first Author (along with a mutual colleague and friend of GC) visited at home with GC's second wife Alison (Myra passed away in 1983) and during the visit ensured that the Cornish Family also retained copies of the first Author's recordings, which were gratefully received. The recorded audio messages are simple but most revealing of GC's passion for his walking program, genuine care for others, humour, and gentle yet uplifting manner:

o “Keep on walking, and you'll keep on smiling”

o "What a heart!"

o "Sure and steady wins the race, going at a constant pace"

o "Give yourself, a part on the back"

o “It's all happening”

o "A healthy heart, means a healthy body"

o "You are a lean, mean, cardiac machine"

o "Nice and constant, that's the way"

o “Chin up, shoulders back”

o "You're a credit to the Cornish Walkers" 
The ten audio messages above add to the continuing inspirational social legacy of GC. As an example of how this legacy with its new addition continues to inspire even today's youth, the year 11 Physics class at Caloundra City Private School, Sunshine Coast, Queensland, in 2016 undertook an assignment, "The Physics of the Cornish Walking Program". As a small class of five, the students voluntarily undertook an adjunct computer interfacing and instrumentation project involving the development of: electronic sensor circuitry, software coding, and interactive display which both played the audio messages and presented key facts on the GC story.

The students' enthusiasm and collegial collaboration in undertaking the project with necessary background research was inspiring for the teacher (the first Author). Furthermore, the manner in which the students embraced and held strong senses of appreciation for, and connectedness to, the GC story, and proudly and seriously showcased their project to others (including year 12 students), demonstrates that GC's inspiration remains positively influential on today's youth.

However, of all the dimensions of the GC story, in the first Author's view it would be amiss to conclude this letter with anything other than GC's simple and direct message within Vetaffairs [7] via a journalistic title that arguably represents what GC would hope to be his primary inspirational legacy to the health of society:

“Walking should be a way of life, says Doc Cornish”.

\section{REFERENCES}

1. Hayes H. 2004 Beyond the great escape: Geoff Cornish, the one who got away, 1st ed. Elanora, Queensland: Possum Publishing.

2. Cornish G. As it happened by Geoffrey Cornish AO [Internet, publication date unknown]. Australian Gold Coast Branch of the Aircrew Association [cited 2021 April 27]. Available from:

https://www.airforce.gov.au/sites/default/files/minisite/static/7522/RAAFm useum/aircrewaca/aih/aih18-cornish.pdf

3. University of New South Wales and Australian Government Department of Veterans' Affairs. 2004 Australians at war film archive number 1388 [internet]. Department of Veterans' Affairs [cited 2021 April 27]. Available from: http://australiansatwarfilmarchive.unsw.edu.au/archive/1388-geoffcornish

4. Harper H. 1996 Twenty two temporary gentlemen, 1st ed. Burradoo, New South Wales: H. Harper.

5. Marshall C. 2003 Local man's role in the Great Escape prison break [internet]. Australian Broadcasting Corporation [cited 2021 April 27]. Available from:

https://www.abc.net.au/local/stories/2013/03/25/3723188.htm

6. Perry A. 2016 Stories of Drouin: Dr Geoff Cornish as told by Adele Perry to Judy Farmer and Lynn Wells [internet]. Committee for Drouin, Community Radio Station 3BBR FM and the Drouin History Group [cited 2021 April 27]. Available from: https://www.storiesofdrouin.com.au/drgeoff-cornish

7. Australian Government Department of Veterans' Affairs. 1993 Walking should be a way of life, says Doc Cornish. Vetaffairs March, 5 .

\section{AUTHORS' CONTRIBUTIONS}

The second Author made available all photographs, most with captioning, and wrote Section 3 (integrated within the letter via minor editorial adjustments). The first Author wrote all remaining Sections (with second Author materials incorporated accordingly into Section 2 and the Appendix), and recorded and provided the GC audio messages of inspiration.

\section{ACKNOWLEDGMENTS}

While between Author acknowledgments are atypical, the first Author sincerely thanks the invited collaborating second Author (daughter of GC) for generosity in contributing: personal memories, the letter's cherished and rare Family photographs (several previously unpublished), and considerable time and warm spirit within several correspondences. 


\section{APPENDIX - COLLAGE OF ADDITIONAL PHOTOGRAPHS}

The following collage presents a collection of additional or full version photographs provided by the second Author and which were not included within the letter's main body. While being of historical interest in several cases, some of the photographs also uniquely reflect the highly personalised dimension of the letter. Descriptions of some of the less self-explanatory photographs include: A framed silk map (showing only a little of the English coastline) that was sewn into the shoulder pads of RAF Air Crew uniforms; full image of the Bronte Park celebration photograph; dinner with "Dellie Medicos" and partners; full image of the wedding cake (decorated by GC) photograph; and full image of the bracelet purchased by GC with his first earnings as a doctor - it is now a Family charm bracelet that includes the silk caterpillar earned by GC but also added Welsh spinning wheel, daffodil (flower of Wales), English rose, and London double-decker bus, all symbolising the Welsh, English and Cornish heritage and connections of Myra/GC. The more recent lifelong Family friends photograph includes from left to right at back, GC’s daughter Sue, Flo Erskine and son Paul, and Vonnie Erskine, with GC's daughter Adele and GC in front.
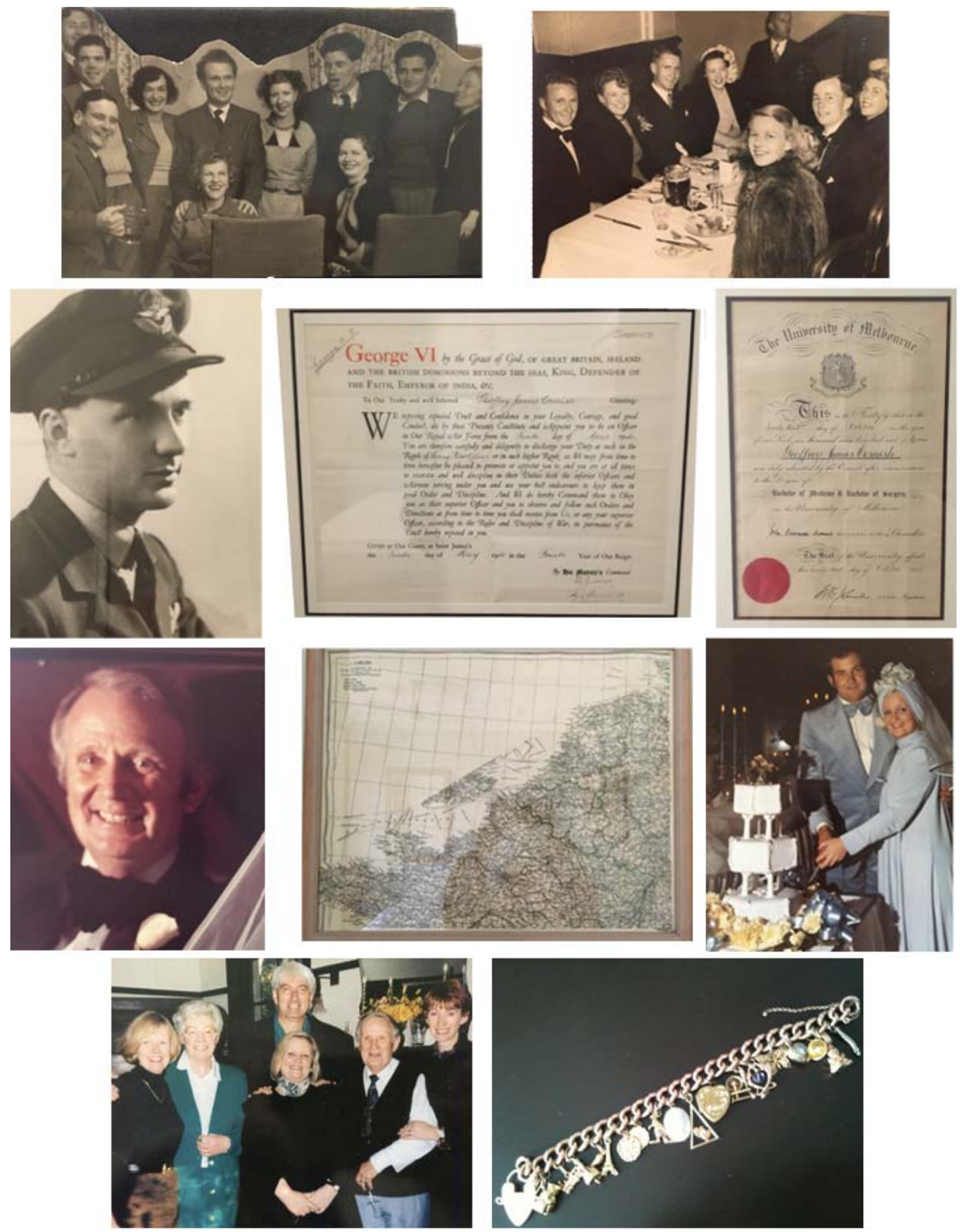